\title{
Application of Geographic Information System for forward planning of the Russian Federation subject rural areas
}

\author{
Svetlana Sheina ${ }^{1}$, Albina Fedorovskaya ${ }^{1, *}$, and Anastasia Serdiukova ${ }^{1}$ \\ ${ }^{1}$ Don State Technical University, 1 Gagarina square, Rostov-on-Don, Russia
}

\begin{abstract}
The present article deals with the issues of elaboration and analysis of methods of rural areas planning within the framework of agroindustrial complex development in Rostov Region. In order to ensure a possibility of forward planning for the rural areas, a method of development planning for agro-industrial complex in the Russian Federation subject has been elaborated. This method consists of 5 stages and comprises analysis of agriculture development on both regional and federal levels, and foresees a transition onto the local level for each AIC object. Algorithm of land suitability for agricultural purposes underlies this method. This article describes all stages of algorithm implementation. One of the implementation stages is the identification of criteria for sustainable development of rural areas. Based on the mentioned criteria, and with the use of ArcGIS ESRI software, electronic maps demonstrating the natural resources potential, anthropogenic impact on the areas, and the existing situation regarding the development of agricultural industry branches in the region. Generation and analysis of electronic maps allowed to carry out a comprehensive evaluation of the Rostov Region territory. This article also covers a calculation of functional ranking, based on which the territories of the utmost priority for agricultural industry development have been identified in the region.
\end{abstract}

\section{Introduction}

The main task of territorial planning of the subject of the Russian Federation is to provide such spatial organization of the territory that will contribute to sustainable development of all sectors of the economy and will provide favourable living conditions for the population, protection and rational use of natural resources.

The concept of long-term social and economic development of the Russian Federation for the period until 2020 sees the sustainable development of rural areas, raising the standard of living of the rural population as one of the main objectives of the state policy in agriculture in the long term. The transition to the concept of sustainable development of the territories of the Russian Federation requires in its turn an implementation of comprehensive approach to the study of historical, social and natural and ecological

\footnotetext{
* Corresponding author: bina-87@mail.ru
} 
features of the territory, as these underlie sustainable nature management, preservation of cultural and ethnic identity and social welfare for the territories [1].

Presently, the issue of creating a tool to ensure prompt retrieval of information on the status and use of agricultural land on the basis of state monitoring of agricultural land remains crucial. The development of state monitoring for such lands on the federal and regional levels and the formation of state information resources on agricultural lands will allow for the operational management of lands [2].

The process of planning and development of the agro-industrial complex can be optimized by creating a comprehensive management system for the agro-industrial complex of municipal entities that will take interaction between various factors and their impact on the stability of the territorial system into account. Thus, it is necessary to adapt the methodology for conducting a comprehensive evaluation and analysis of the agricultural potential of the territory to the conditions of Rostov Region in order to have a possibility of long-term planning for the development of rural areas.

To enable long-term planning of the rural areas development in the subject of the Russian Federation, a method for planning the development of the agro-industrial complex of the subject of the Russian Federation has been elaborated. The method consists of 5 stages including: creation of an analytical base for making project decisions, identification of criteria for evaluation of the territory stability, analysis of the territory on the regional level, conduction of a comprehensive assessment and the transition to a local level for a specific APC object (figure 1).

Creation of an analytical base for making managerial decisions concerning the planning of rural areas takes place on the first stage of method implementation. Background data for this stage are:

- territorial planning schemes;

- normative and regulatory acts in the sphere of agriculture;

- strategy of social and economic development of the region;

- sustainable development strategy for the period until 2030.

Stage I: Creation of an analytical base for making project decisions to generate schemes of territorial development of the region

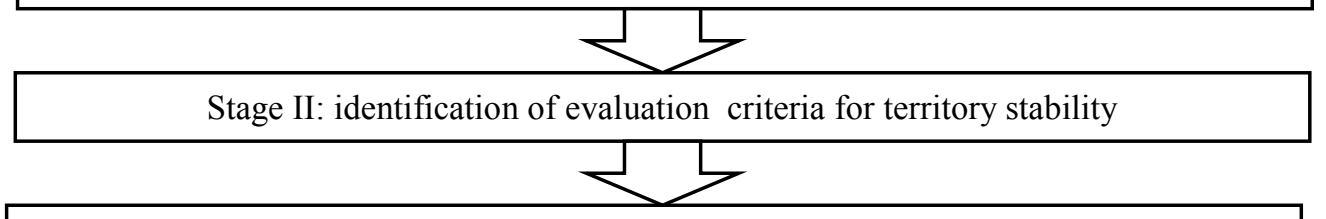

Stage III: transition to the regional level of analysis of conditions on the territory of a given Russian Federation subject

Stage IV: comprehensive assessment of the subject territory, evaluation of functional ranking of development of the areas before and after taking environmental measures

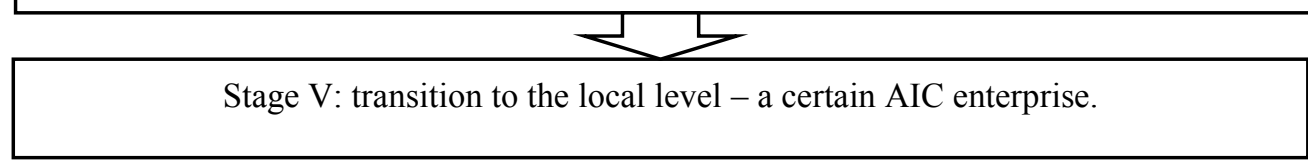

Fig. 1. Method of AIC planning for the Russian Federation subject

One of the key stages of AIC planning method implementation for the Russian Federation subject is the identification of sustainability criteria. Sustainability criteria are 
quantitative and qualitative characteristics of the social and economic, and natural and environmental potential of territorial systems, on the basis of which the sustainability of rural area development is assessed [3]. There are 4 groups of criteria; these are shown in Table 1 below.

Sustainable development of any territory is determined by a combination of these factors. Failure to take any of these into account entails imbalance and disruption of the development process. The basis for accounting for all factors is the methodology of system analysis, which allows us to reveal these factors and identify all interrelations between them. Only after this, it is possible to develop a strategy for addressing the problems of sustainable development in any particular rural area [4].

Table 1. Sustainability Evaluation Criteria for Rural Areas

\begin{tabular}{|c|c|c|}
\hline No. & Group of criteria & Criterion \\
\hline \multirow[t]{9}{*}{1.} & \multirow[t]{9}{*}{ Economic potential } & 1.1. Natural resources endow \\
\hline & & - Soil fertility \\
\hline & & - Arable lands \\
\hline & & - Pastures \\
\hline & & 1.2. Economic evaluation \\
\hline & & - Remoteness from sales markets \\
\hline & & - Business activity \\
\hline & & - Development of agricultural processing \\
\hline & & - Availability of agricultural; machinery \\
\hline \multirow[t]{5}{*}{2.} & \multirow[t]{5}{*}{ Utilities infrastructure } & - Water supply \\
\hline & & - Roadways \\
\hline & & - Gas supply \\
\hline & & - Electric power \\
\hline & & - Communication services \\
\hline \multirow[t]{5}{*}{3.} & \multirow[t]{5}{*}{ Social development } & - Education \\
\hline & & - Public health \\
\hline & & - Housing \\
\hline & & - Employment of population \\
\hline & & - Level of poverty \\
\hline \multirow[t]{5}{*}{4.} & \multirow[t]{5}{*}{ Quality of environment } & - Pollution of atmosphere \\
\hline & & - Background radiation \\
\hline & & - Soil erosion \\
\hline & & - Water quality \\
\hline & & - Recreational zones \\
\hline
\end{tabular}

\section{Experimental section}

Comprehensive evaluation of the territory is a comparative planning estimate of individual sections of the entire territory of the region based on a complex of natural and anthropogenic factors from the point of view of the favourable nature of these sections for locating the main types of economic activities there [6,7].

A comparative analysis of the territory has been carried out with the use of geographic information systems actively implemented in the processes of territorial development managing, especially in the spatial analysis of territories. The use of GIS helped to make a 
comprehensive spatial analysis of the territory according to the provisions of the Strategy of Social and Economic Development of Rostov Region until 2020, official statistical indicators of the Federal State Statistics Service, and also the data of environmental monitoring in Rostov Region.

For the purpose of comprehensive evaluation of the territory, Rostov Region has been divided into 55 sections for evaluation.

The limits of such sections correspond to the administrative borders of municipal entities, i.e. municipal areas and city and town districts of Rostov Region.

Comprehensive evaluation of the territory in the regional planning involves a comparative assessment of different sections of the entire territory of the region based on a complex of natural and anthropogenic factors in terms of territory's favourable nature for locating the main types of economic activities. Based on the comprehensive evaluation of natural and anthropogenic factors, reserve areas for economic development and construction are identified and allocated.

The favourability of territory for agricultural use is determined by means of assessment of terrain, climate, soils, water resources (irrigation capacity), transport and utility networks, environmental conditions, distance to major centres. At the initial stage of the comprehensive evaluation of rural areas, data on the state of the agro-industrial complex of the subject are analyzed and the information base in accordance with the evaluation criteria is created.

Relative value factors have been identified on the basis of evaluation criteria for the sustainability of the territories and actualized by taking into account the specifics of Rostov Region, as reflected in the Strategy of social and economic development of the region until 2020; these factors are an integral part of the comprehensive management system for the development of the territory described earlier.

Based on the sustainability criteria, 12 evaluation factors have been identified for the comprehensive evaluation of the Russian Federation subject rural areas, assessments as per natural factors and anthropogenic load are represented on the illustrations below (figures 2 $a, b)$.

a)

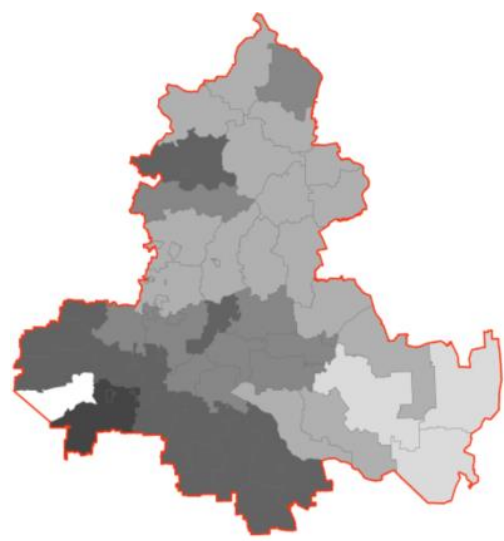

b)

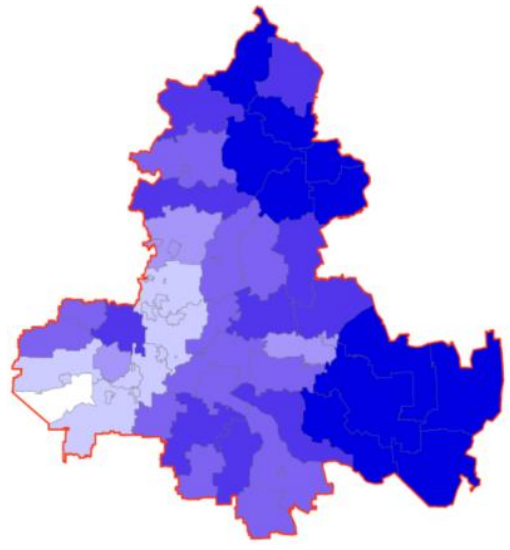

Fig. 2. Integral assessment: a) as per natural factors, b) as per anthropogenic load

The next stage following the comprehensive evaluation is the stage of functional rating assessment which comprises the following:

1. Selection of functions (types of functional purpose) for assessment;

2. Determination of ranking coefficients for evaluation factors;

3. Calculations of functional ranking;

4. Formation of functional ranking evaluation results. 
The functional ranking assessment results in allocation of the highest-priority territories in Rostov Region for the development of agricultural industry branches and location of a particular AIC enterprise.

Ranking assessment of the Rostov Region territory for the development of agriculture and location of agricultural enterprises has been carried out in three branches of agricultural specialization: crop farming, livestock breeding, and agricultural processing.

Determination of ranking coefficients for estimation factors takes place by generating a priority matrix. Calculation of the ranking coefficients of the relative value factors for different types of agricultural specialization of the territory has been carried out by analyzing the initial information obtained by the expert survey method.

Following the matrix generation (see table 2), the priority is calculated for the areas selected for the previously selected types of agricultural specialization. The type of agricultural specialization of the territory with the highest ranking can be found via analysis of the relative value factors of the territory.

Table 2. Priority Matrix

\begin{tabular}{|c|l|l|l|l|l|l|l|}
\cline { 2 - 7 } \multicolumn{1}{c|}{} & $q_{1}$ & $q_{2}$ & $q_{3}$ & $q_{4}$ & $q_{5}$ & $\ldots$ & $q_{n}$ \\
\hline$r_{1}$ & & & & & & & \\
\hline$r_{2}$ & & & & & & & \\
\hline$r_{3}$ & & & & & & & \\
\hline$r_{4}$ & & & & & & & \\
\hline$r_{5}$ & & & & & & & \\
\hline$\ldots$ & & & & & & & \\
\hline$r_{n}$ & & & & & & & \\
\hline
\end{tabular}

In the course of comprehensive evaluation, the numerical indicators of the evaluation factors severity are summed for each section under evaluation to form a coefficient of relative value for the territory denoted as $\mathrm{Q}$ (eq.1).

$$
Q=q_{1}+q_{2}+\ldots+q_{n}
$$

With the use of priority matrix, and in accordance with the identified factors, the relevance coefficients $(\mathrm{R})$ are determined for each type of agricultural specialization.

As a result of multiplying the priority matrix by the results of the comprehensive evaluation of the territory, an agricultural priority ranking is obtained for the selected specialization types. Thus, the formula for calculating the target function has the following form (eq. 2):

$$
P=\sum Q_{i} \cdot R_{i \max }^{j}
$$

where $\mathrm{Q}$ is ith coefficient of the territory's relative value;

$\mathrm{R}$ is the relevance coefficient of the ith factor for jth type of industrial specialization;

$\mathrm{P}$ is the value indicator (priority of utilization) for jth type of industrial specialization of the territory.

Selection of the highest-priority territories for the development of agriculture is carried out according to the maximum value of the target priority function. Because of the assessment, electronic priority maps for the development of territories for each type of specialization were constructed. As a result of the evaluation, electronic priority maps for territories development as per each type of specialization have been generated. The 
distribution of the agricultural priority ranking for the location of crop farming, livestock breeding and agricultural processing enterprises in Rostov Region is shown in figures $3 \mathrm{a}$, $3 \mathrm{~b}$ and $3 \mathrm{c}$, respectively.

a)

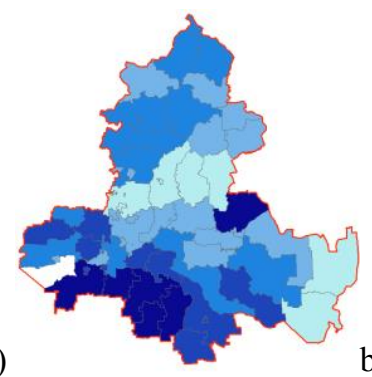

b)

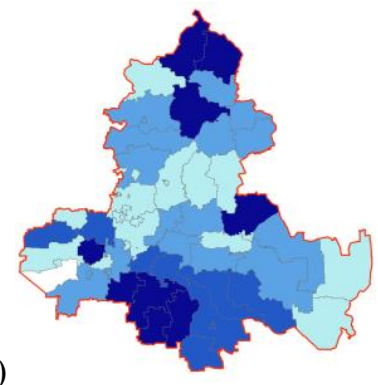

c)

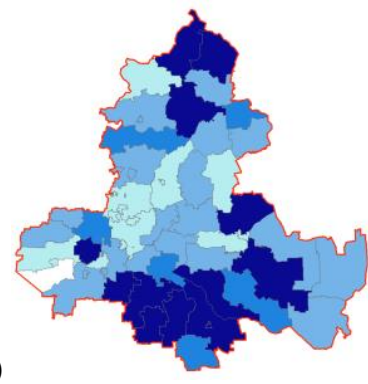

Fig. 3. Distribution of the agricultural priority ranking for the location of: a) crop farming, b) livestock breeding, c) agricultural processing enterprises in Rostov Region

Comprehensive evaluation and functional ranking allowed to generate the priority rating for Rostov Region territories from the position of agricultural development. In order to improve agricultural feasibility of territories which, as a result of evaluation, received a low priority rating, a set of environmental measures is implemented [8].

Implementation of the said measures in the areas with low rating results in the improvement of indicators and, consequently, in the growth of the priority ranking of the territory for the development of agriculture (see table 3). This process represents a modeling of the agricultural priority increase process for the territory.

Table 3. Results of Implementation of Environmental Measures

\begin{tabular}{|l|l|l|}
\hline Factor & Measures & $\begin{array}{l}\text { Efficiency (result of } \\
\text { improvement) }\end{array}$ \\
\hline $\begin{array}{l}\text { State of } \\
\text { ambient air }\end{array}$ & $\begin{array}{l}\text { Establishment of sanitary protection } \\
\text { zones, treatment plants, introduction of } \\
\text { technologies with lower emissions, } \\
\text { purification of emissions from } \\
\text { impurities }\end{array}$ & $\begin{array}{l}\text { Reduction of the integral } \\
\text { index of atmospheric } \\
\text { pollution }\end{array}$ \\
\hline $\begin{array}{l}\text { Pollution of soils } \\
\text { with heavy metals }\end{array}$ & $\begin{array}{l}\text { Elaboration of systems for waste } \\
\text { handling into secondary material } \\
\text { resources; replacement of toxic wastes } \\
\text { with non-toxic ones; replacement of } \\
\text { non-recyclable waste with recyclable } \\
\text { waste. }\end{array}$ & $\begin{array}{l}\text { Reduction of the level of } \\
\text { soil pollution, reduction of } \\
\text { the amount of waste } \\
\text { entering the soil }\end{array}$ \\
\hline $\begin{array}{l}\text { Quality of water } \\
\text { for human } \\
\text { consumption }\end{array}$ & $\begin{array}{l}\text { Development of various types of } \\
\text { drainless process systems and water } \\
\text { extraction cycles based on wastewater } \\
\text { treatment methods }\end{array}$ & $\begin{array}{l}\text { Reduction of the amount } \\
\text { of wastewater discharges } \\
\text { and concentration of } \\
\text { pollutants therein }\end{array}$ \\
\hline $\begin{array}{l}\text { Ecological } \\
\text { potential of the } \\
\text { territories }\end{array}$ & $\begin{array}{l}\text { Removal of industrial enterprises from } \\
\text { large cities and construction of new } \\
\text { enterprises in sparsely populated areas } \\
\text { with the lands that are unsuitable and/or } \\
\text { hardly suitable for agricultural use }\end{array}$ & $\begin{array}{l}\text { Improvement of the } \\
\text { integrated index as per } \\
\text { quality of the environment } \\
\text { in the region [9] }\end{array}$ \\
\hline
\end{tabular}




\section{Conclusions}

The method that has been developed for the planning of AIC development of the Russian Federation subject is universal and can be implemented for area planning schemes generation, for elaboration of social and economic development strategies for the Russian Federation subjects.

Implementation of the developed algorithm for the territory of a specific subject of the Russian Federation enables the identification of the most suitable sites for placement of certain agricultural enterprises, production facilities, and organization of recreational zones. On the basis of these data, it is possible to regulate the use of the territory in accordance with the main functions, to establish the optimal utilization regime of each territorial zone, to determine the sequence of development of sites taking into account the complexity of development thereof.

\section{References}

1. Forecast of the long-term socio-economic development of the Russian Federation for the period until 2030

2. Z. Ivanova, O. Yudenkova, J. Naimaviciene, J. MATEC Web of Conferences 73, 07008 (2016)

3. Sustainable economic development. Criteria and indicators of sustainable development on URL: http: //www.stud-files.ru/preview/3102566/

4. L. Girya, S. Sheina, P. Fedyaeva, Journal of Applied Engineering Research 8, 1926319276 (2015)

5. N.A. Urazaev, Agricultural ecology: textbooks and teaching aids for students of higher educational institutions (Moscow, 2002)

6. S. Sheina, A. Khamavova, J. Procedia Engineering 150, 1960-1965 (2016)

7. S. Sheina, W. Dietmar, R. Matveyko, L. Teryukova, J. European science review 11-12, 214-219 (2015)

8. S. Sheina, A. Fedorovskaya, J. MATEC Web of Conferences 106, 07010 (2017)

9. P. Graboviy, J. Procedia Engineering 165, 1520-1528 (2016)

10. V. Kas'janov, A. Lyapin, O. Chernysheva, J. Vestnik MGSU 8, 50-57 (2011)

11. P. Grabovy, A. Naumov, I. Avilova, International Business Management 10, 13541364 (2016)

12. E. Shcherbina, N. Danilina, J. Proceedings of Irkutsk State Technical University 1, 183-186 (2014) 